\title{
Studi Eksperimental Perbandingan Nilai Faktor Reduksi $(\phi)$ Profil Baja Tabung Kotak di Indonesia
}

\author{
Nawir Rasidi \\ Jurusan Teknik Sipil Politeknik Negeri Malang
}

\begin{abstract}
Abstrak. Selama ini nilai Faktor Reduksi $(\phi)$ mengikuti ketetapan dari LRFDAISC (Load and Resistance Factor Design - American Institute of Steel Construction). Nilai faktor reduksi $(\phi)$ itu sendiri ditetapkan sesuai kondisi USA (United State of America). Padahal kondisi Indonesia berbeda dalam hal mutu baja hasil pabrikasi dengan kondisi USA. Karena itu dilakukan penelitian untuk menentukan besar faktor reduksi $(\phi)$ untuk kondisi Indonesia.

Penelitian dilakukan untuk menentukan faktor reduksi $(\phi)$ dengan indeks keandalan $(\beta)=3$ sesuai acuan LRFD. Perilaku tekan dan lentur benda uji berupa baja tabung kotak ukuran $(2 \times 4) \mathrm{cm}$ dengan panjang untuk pengujian tekan $75 \mathrm{~cm}$ dan untuk pengujian lentur $65 \mathrm{~cm}$. Pengujian ini mengumpulkan data tahanan yaitu tegangan baja, luas penampang, modulus penampang dan beban.

Hasil dari pengujian lentur dengan $\beta=3$ diperoleh nilai faktor reduksi lentur, $\phi_{\mathrm{b}}=0.8823$. Untuk pengujian tekan dengan $\beta=3$ diperoleh nilai faktor reduksi tekan $\phi=0.5195$. Perbedaan nilai ini dibandingkan dengan nilai faktor reduksi LRFD-AISC disebabkan oleh antara lain : Rasio harga rata-rata nominal dengan harga rata-rata, koefisien variasi $(\Omega)$ dari variabel serta distribusi yang dipergunakan dalam perhitungan. Selain itu, dilakukan juga perhitungan untuk faktor reduksi $(\phi)$ dengan tingkat keandalan yang berbeda yaitu : 2,$5 ; 2 ; 1,5$ untuk masing-masing perilaku. Diperoleh dari perhitungan bahwa dengan semakin kecil indeks keandalan $\beta$ maka nilai faktor reduksi $(\phi)$ semakin besar.
\end{abstract}

Kata kunci: faktor reduksi ( $\phi)$; profil tabung kotak; indeks keandalan.

Abstract. At present, structural designing in Indonesia uses the value of reduction factor $(\phi)$ according to LRFD-AISC regulation (Load and Resistance Factor Design - American Institute of Steel Construction). It is understood that different condition in Indonesia requires different approach, therefore this research attempted to determine a specific value of reduction factor $(\phi)$.

The research observes the compression and flexural behavior of profile steel boxes $(2 \times 4) \mathrm{cm}$ with length $75 \mathrm{~cm}$ and $65 \mathrm{~cm}$ for compression and flexural test, respectively. This test collects resistance data that are stress, area of steel, load and modulus of elasticity.

The result of flexural test with reliability index $(\beta)=3$ obtained the value of reduction factor of flexure $\phi_{\mathrm{b}}=0.8823$ and $\phi=0.5195$ for compression test. Difference between this value and that of LRFD-AISC code were caused by nominal mean value-mean value ration, coefficient of variation $(\Omega)$, and the

Makalah diterima redaksi tanggal 14 Februari 2005. 
distribution used in the calculation. In addition, different reliability index of 2.5, 2 , and 1.5 were also calculated for comparison. It is concluded that greater value of reduction factor $(\phi)$ could be obtained with smaller reliability index $(\beta)$.

Keywords: reduction factor ( $\phi$ ); steel box profile; reliability index.

\section{$1 \quad$ Pendahuluan}

Dalam merencanakan suatu struktur mengacu pada peraturan perencanaan bangunan yang ada. Peraturan ini dibuat untuk dengan harapan akan didapatkan keamanan struktur yang menjamin baik terhadap kemungkinan kelebihan beban (overload) atau kurang kekuatan (understrength). Resiko runtuh yang disebabkan oleh ketidakpastian dalam proses perencanaan tidak dapat dihindari dan angka kemanan yang diberikan dalam perencanaan merupakan suatu usaha untuk memperkecil resiko runtuh pada struktur. Salah satu studi yang berkembang untuk menentukan keamanan struktur adalah menggunakan metode probabilitas. Dengan metode probabilitas ini beban yang bekerja (beban mati, beban hidup, beban angin dan lain-lain) maupun resistensi (tahanan), ragam keruntuhan (lentur, geser, tekan atau kombinasi), tenaga kerja dan persepsi manusia mengenai keamanan merupakan variabel-variabel yang harus diperhitungkan serta merupakan variabel acak (random).

Dalam perencanaan kekuatan disain didapatkan harga nominal tahanan $\left(\mathrm{R}_{\mathrm{n}}\right)$ dikalikan reduksi tahanan $(\phi)$. Untuk mendapatkan jumlah beban dikalikan faktor kelebihan beban. Filosofi disain ini dikenal sebagai "disain keadaan batas" yang diacu AISC sebagai Load And Resistance Factor Design. Konsep LRFD ini memberikan nilai faktor reduksi kekuatan sesuai dengan fungsi level keamanan yang diinginkan dan variabilitas ragam keruntuhan yang ditinjau sehingga keamanan struktur lebih rasional.

Selama ini faktor reduksi $(\phi)$ yang digunakan menggunakan faktor reduksi yang ditetapkan berdasarkan kondisi USA. Sedangkan kondisi Indonesia berbeda dengan kondisi USA terutama mutu baja hasil pabrikasi. Karena itu diperlukan adanya faktor reduksi yang sesuai dengan kondisi Indonesia.

\section{Maksud dan Tujuan}

Maksud dan tujuan penelitian ini adalah untuk menentukan besarnya faktor reduksi $(\phi)$ lentur dan tekan untuk kondisi Indonesia dengan tingkat keandalan $\beta=3$ yang ditentukan sesuai LRFD-AISC. Selain itu untuk tingkat keandalan 2,5; 2 dan 1,5 sebagai suatu nilai yang direkomendasikan. 


\section{Tinjauan Pustaka}

Variabilitas tahanan di Indonesia diperkirakan lebih besar daripada di USA, karena itu besar koefisien variasi $\left(\mathrm{C}_{\mathrm{ov}}\right)$ untuk resistensi diperbesar $15 \%$. Berdasarkan indeks keandalan $\beta=3$ diperoleh faktor reduksi untuk lentur dan tekan $=0,8$ (Sidi, 1990).

Faktor reduksi $(\phi)$ terhadap struktur baja di Indonesia yang penelitiannya dilakukan oleh pabrik PT. Gunung Garuda, Bekasi ditetapkan dengan indeks keandalan $\beta=3$ dan beban tetap diperoleh untuk tekan $=0,70$ dan lentur 0,87 (Kristijanto, 1996).

\subsection{Load and Resistance Factor Design (LRFD)}

Dalam LRFD efek beban (Q) dan faktor resistensi (R) diasumsikan variabel bebas random bebas statistik. Pada gambar 1 ditunjukkan distribusi frekuensi untuk Q dan R. Selama resistensi R lebih besar daripada efek beban Q, tersedia margin keamanan untuk keadaan batas. Probabilitas dari keadaan batas ini berhubungan dengan tingkat perpotongan dari distribusi frekuensi seperti dilihat pada gambar 1.

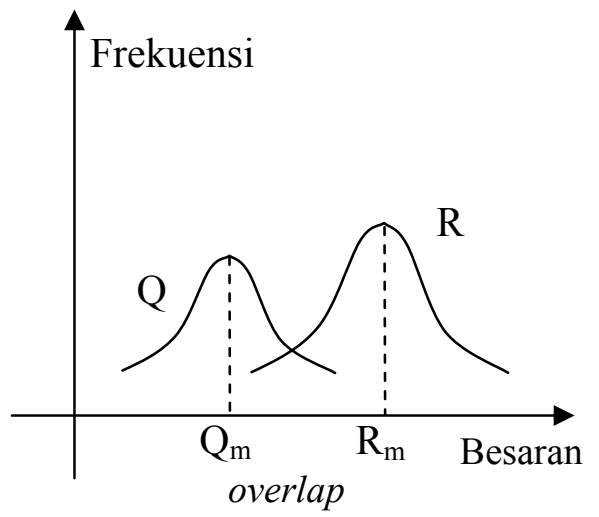

Gambar 1 Distribusi frekuensi beban (Q) dan tahanan (R).

Dimana perpotongan ini tergantung pada posisi relatif $\left(\mathrm{R}_{\mathrm{m}} \mathrm{vs} \mathrm{Q}_{\mathrm{m}}\right)$ dan penyebarannya. Daerah perpotongan ini merupakan probabilitas kegagalan.

Metode yang digunakan untuk mengembangkan LRFD menggunakan nilai ratarata (mean) $\mathrm{R}_{\mathrm{m}}$ dan $\mathrm{Q}_{\mathrm{m}}$ dan deviasi standard $\sigma_{\mathrm{R}}$ dan $\sigma_{\mathrm{Q}}$ dari tahanan maupun beban. Kerapkali, harga rata-rata dan deviasi standar dapat diestimasi sementara distribusi aktualnya tidak dapat diperoleh. Jadi dengan menggunakan kuantitas- 
kuantitas yang dapat diestimasi, deviasi standar $\sigma$ dari $\ln _{(\mathrm{R} / \mathrm{Q})}$ dapat didekati sebagai

$$
\sigma_{\ln (R / Q)} \approx \sqrt{V_{R}^{2}+V_{Q}^{2}}
$$

Margin keamanan adalah jarak dari garis asli sampai ke rata-ratanya dan diwujudkan sebagai perkalian $\beta$ dari $\sigma \cdot \ln _{(\mathrm{R} / \mathrm{Q})}$. Jarak yang mewakili margin keamanan dapat didekati sebagai

$$
\beta=\frac{\ln \left(R_{m} / Q_{m}\right)}{\sqrt{V_{R}^{2}+V_{Q}^{2}}}
$$

Dengan menggunakan kombinasi-kombinasi beban yang difaktorkan menurut standar ANSI (American National Standard Institute), Komite Spesifikasi dan Satuan Tugas AISC telah mengkalibrasi spesifikasi LRFD supaya dapat secara umum sesuai dengan pengalaman yang telah terjadi. Dengan demikian, dalam LRFD factor-faktor resistensi $\phi$ ditetapkan dengan tujuan supaya dapat memperoleh harga-harga $\beta$.

Secara umum, persamaan untuk persyaratan keamanan dapat ditulis sebagai berikut:

$$
\phi R n \geq \gamma_{i} Q_{i}
$$

dimana ruas kiri mewakili resistensi atau kekuatan, dari komponen atau sistem; sedangkan sisi kanan mewakili beban yang diharapkan akan ditanggung. Pada sisi kekuatan, harga nominal resistensi $\mathrm{R}_{\mathrm{n}}$ dikalikan dengan faktor resistensi (reduksi tahanan) $(\phi)$ untuk mendapatkan kekuatan desain (disebut juga kekuatan yang dapat digunakan atau resistensi yang dapat digunakan). Pada sisi beban dari persamaan di atas, berbagai efek beban $\mathrm{Q}_{i}$ (seperti beban mati, beban hidup dan beban salju) dikalikan dengan faktor-faktor kelebihan beban $\gamma_{i}$ untuk mendapatkan jumlah $\Sigma \gamma_{i} Q_{i}$ dari beban-beban terfaktor.

Faktor resistensi $\phi$ bervariasi menurut tipe batang dan keadaan batas yang sedang diperhitungkan. Faktor resistensi $(\phi)$ untuk:

- Batang tarik (LRFD-D1) : $\phi_{\mathrm{t}}=0.90$ untuk keadan batas leleh.

- Batang tekan (LRFD-E2) : $\phi_{\mathrm{c}}=0.85$

\subsection{Probabilitas Resistensi}

Di dalam pengembangan desain rekayasa, pengambilan keputusan kerapkali diperlukan tanpa memandang kelengkapan atau mutu informasi; dengan demikian suatu keputusan biasanya dirumuskan pada keadaan yang tidak pasti, 
dalam pengertian bahwa konsekuensi suatu keputusan tidak dapat ditentukan dengan keyakinan yang sempurna. Di samping kenyataan bahwa informasi seringkali harus diturunkan dari kondisi yang serupa (atau bahkan yang berbeda) atau diturunkan melalui model yang memiliki derajat ketidaksempurnaan yang berbeda-beda, kebanyakan masalah dalam bidang rekayasa mencakup proses dan fenomena alamiah bersifat tak tentu sehingga tidak dapat dijabarkan secara definitif (pasti). Atas alasan ini, keputusan yang diperlukan dalam proses perencanaan (planning) dan desain rekayasa harus dilakukan, dan dilakukan pada kondisi yang tidak pasti. Dari uraian diatas, dapat dilihat bahwa peranan ilmu probabilitas sangat luas dalam bidang rekayasa; peranannya berkisar mulai dari penjabaran informasi sampai kepada pengembangan dasar-dasar desain dan pengambilan keputusan.

Kebutuhan mendasar dalam mempelajari keandalan adalah pengumpulan data dari kekuatan dan sifat fisik lain dari bahan strukturnya dan parameterparameter geometrik penampang serta analisis statistiknya.

Tegangan leleh $\mathrm{f}_{\mathrm{y}}$ dan modulus elastisitas baja Es adalah dua sifat fisik utama dari baja yang biasa digunakan dalam perencanaan struktur baja. Variasi dari tegangan leleh baja dipengaruhi oleh berbagai faktor diantaranya : kekuatan bahan, luas tampang, kecepatan pembebanan pada saat pengujian dan efek regangan pada saat leleh.

Benda uji diuji di laboratorium dan hasil uji seluruh sampel yang diambil dikumpulkan dan kemudian dihitung nilai rata-rata dan standar deviasinya. Hasil dari pengujian ini dapat digambarkan dalam satu histogram seperti terlihat pada gambar 2.

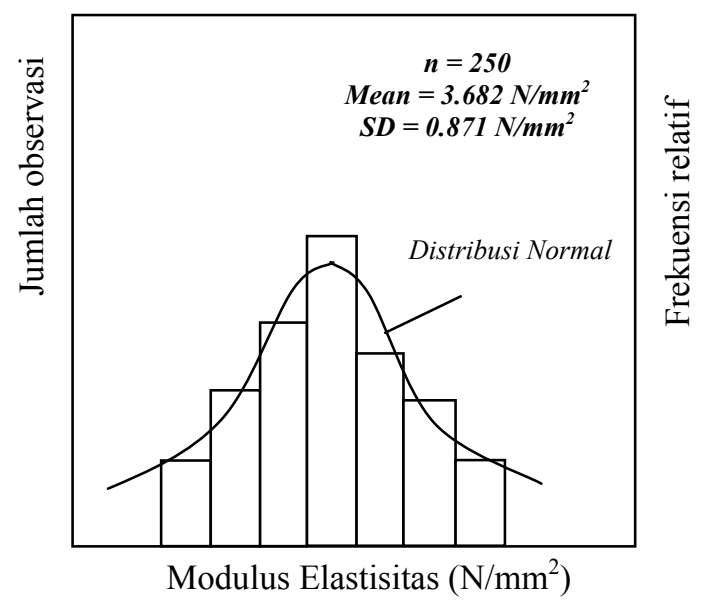

Gambar 2 Frekuensi distribusi tegangan leleh baja 415 Mpa. 


\subsection{Second - Moment Formulation}

Perhitungan probabilitas keamanan atau probabilitas keruntuhan, mensyaratkan pengetahuan mengenai distribusi $\mathrm{f}_{\mathrm{x}}(\mathrm{x})$ dan $\mathrm{f}_{\mathrm{y}}(\mathrm{y})$, atau distribusi joint $\mathrm{f}_{\mathrm{x}, \mathrm{y}}(\mathrm{x}, \mathrm{y})$. Dalam prakteknya informasi ini sering tidak tersedia atau sulit untuk diperoleh karena alasan ketidakcukupan data. Tidak jarang informasi yang tersedia atau data hanya cukup untuk mengevaluasi first and second moments yaitu nilai rata-rata dan nilai varians dari masing-masing variabel random. Pengukuran secara praktis keamanan atau keandalan sering sekali terbatas fungsinya dari dua momen pertama. Pendekatan second moment konsisten dengan normal ekivalen dari distribusi non-normal (Ang \& Tang, 1984).

$$
X^{\prime}=\frac{X-\mu_{x}}{\sigma_{x}}
$$

Reduced variates:

$$
Y^{\prime}=\frac{Y-\mu_{y}}{\sigma_{y}}
$$

Margin keamanan : $\mathrm{M}=\mathrm{X}-\mathrm{Y}$

Keadaan aman dari sistem : $\mathrm{M}>0$

Keadaan keruntuhan dari sistem : $\mathrm{M}<0$

Pemisahan batasan dari keadaan aman dan runtuh adalah keadaan batas (limit state) yang didefinisikan oleh persamaan $\mathrm{M}=0$ dan ditunjukkan pada gambar 3.

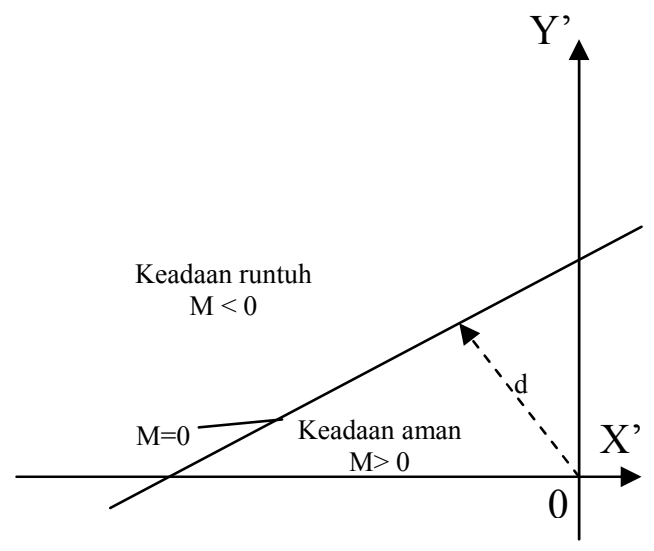

Gambar 3 Reduced variates X' dan Y'.

d pada gambar 3 menunjukkan indeks keandalan $\beta$. 
Dalam bentuk reduced variates, persamaan keadaan batas $\mathrm{M}=0$ menjadi:

$$
\begin{aligned}
& \sigma_{x} X^{\prime}-\sigma_{y} Y^{\prime}+\mu_{x}-\mu_{y}=0 \\
& d=\frac{\mu_{x}-\mu_{y}}{\sqrt{\sigma^{2}{ }_{x}+\sigma^{2}{ }_{y}}}
\end{aligned}
$$

Jarak minimum, $d_{\min }=\beta$ pada titik keruntuhan yang paling mungkin terjadi:

$$
\begin{gathered}
\beta=\frac{-\sum_{i}{x^{\prime \prime}}_{i}\left(\frac{\partial g}{\partial X_{i}^{\prime}}\right)_{*}}{\sqrt{\sum_{i}\left(\frac{\partial g}{\partial X_{i}^{\prime}}\right)_{*}^{2}}} \\
x_{i}^{\prime *}=-\alpha_{i} * \beta
\end{gathered}
$$

dimana:

$$
\alpha_{i}^{*}=\frac{\left(\frac{\partial g}{\partial X_{i}^{\prime}}\right)_{*}}{\sqrt{\sum_{i}\left(\frac{\partial g}{\partial X_{i}^{\prime}}\right)_{*}^{2}}}
$$

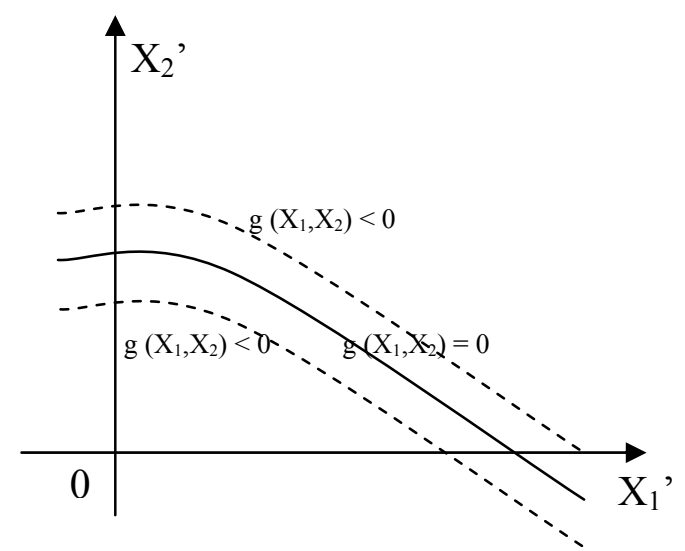

Gambar 4 Keadaan aman dan runtuh pada ruang reduced variates. 


\subsection{Distribusi Normal Eqivalen}

Sejauh ini, nilai mean dan standar deviasi terdistribusi normal. Akan tetapi dalam situasi nyata banyak variabel dasar non-normal. Pada beberapa kasus, nilai $\beta$ atau $p_{f}$ dihasilkan dengan menggunakan distribusi normal. Akan tetapi dalan situasi nyata banyak variabel dasar non-normal. Pada beberapa kasus, nilai $\beta$ atau $p_{f}$ dihasilkan dengan menggunakan distribusi normal dengan melakukan transformasi variabel non-normal ke variabel normal.

Persamaan probabilitas kumulatif pada titik keruntuhan $\mathrm{x}_{\mathrm{i}}{ }^{*}$ :

$$
\Phi\left(\frac{x_{i}^{*}-\mu_{x_{i}}^{N}}{\sigma_{x_{i}}^{N}}\right)=F_{x_{i}}\left(x_{i}^{*}\right)
$$

dimana:

$\mu_{x_{i}}^{N}, \sigma_{x_{i}}^{N}=$ Nilai mean dan standar deviasi distribusi normal ekivalen untuk $X_{i}^{*}$.

$F_{x_{i}}\left(x_{i}^{*}\right)=\mathrm{CDF}$ dari $\mathrm{X}_{\mathrm{i}}$ dinilai pada $x_{i}^{*}$.

Persamaan diatas kemudian menghasilkan:

$$
\begin{aligned}
& \mu_{x_{i}}^{N}=x_{i}^{*}-\sigma_{x_{i}}^{N} \Phi^{-1}\left[F_{x}\left(x_{i}^{*}\right)\right] \\
& \sigma_{x_{i}}^{N}=\frac{\phi\left\{\Phi^{-1}\left[F_{x_{i}}\left(x_{i}^{*}\right)\right]\right\}}{f_{x_{i}}\left(x_{i}^{*}\right)}
\end{aligned}
$$

Superscript $\mathrm{N}$ menunjukkan statistik untuk distribusi normal ekivalen. Titik keruntuhan adalah:

$$
\begin{aligned}
x_{i}^{N} & =\sigma_{x_{i}}^{N} x_{i}^{\prime *}+\mu_{x_{i}}^{N} \\
& =-\alpha_{i} \beta \sigma_{x_{i}}^{N}+\mu_{x_{i}}^{N}
\end{aligned}
$$

\subsection{Kriteria Perencanaan Berdasarkan Probabilitas}

Format LRFD adalah salah satu bentuk kriteria perencanaan factor of safety yang menggunakan faktor kelebihan beban dan faktor reduksi resistensi. Faktor disain yang mencapai tingkat persyaratan dari keandalan $\mathrm{p}_{\mathrm{s}}$. Faktor desain tentunya untuk menutupi ketidakpastian karena kekuranglengkapan informasi.

Bentuk disain yang paling umum adalah melakukan disain faktor masingmasing variabel yang dikenal sebagai "partial factors". 
Faktor disain parsial yang diminta:

$$
\overline{\gamma_{i}}=\frac{x_{i}^{*}}{\mu_{x_{i}}}
$$

Perhitungan faktor disain juga masalah perhitungan kemungkinan terbesar titik keruntuhan, $x_{i}^{*}$. Pada reduce variate, kemungkinan terbesar titik keruntuhan adalah:

$$
x_{i}^{\prime *}=-\alpha_{i} * \beta
$$

dimana

$$
\alpha_{i}^{*}=\frac{\left(\frac{\partial g}{\partial X_{i}^{\prime}}\right)_{*}}{\sqrt{\sum_{i}\left(\frac{\partial g}{\partial X_{i}^{\prime}}\right)_{*}^{2}}}
$$

dari persamaan (11) dan (12) didapatkan variates dan faktor disain (Ang \& Tang,1984):

$$
\begin{aligned}
x_{i}^{*} & =\mu_{x_{i}}-\alpha_{i}^{*} \beta \sigma_{x_{i}} \\
& =\mu_{x_{i}}\left(1-\alpha_{i}^{*} \beta \Omega_{x_{i}}\right) \\
\gamma_{i} & =1-\alpha_{i}^{*} \beta \Omega_{x_{i}}
\end{aligned}
$$

\section{$4 \quad$ Metodologi Penelitian}

Sesuai tujuan dari penelitian ini yaitu menentukan besarnya nilai faktor reduksi $(\phi)$ maka dilakukan penelitian untuk mengumpulkan data berupa data statistik tahanan yaitu tegangan baja dan geometri penampang.

Benda uji berupa baja tabung kotak ukuran $(2 \times 4) \mathrm{cm}$ dengan tebal $0.22 \mathrm{~cm}$ Dilakukan pengujian tekan dan lentur dengan panjang untuk pengujian tekan 75 $\mathrm{cm}$ dan pengujian lentur $65 \mathrm{~cm}$. Benda uji masing - masing 7 buah. Peralatan yang digunakan untuk penelitian ini : loading frame, hydraulic jack dan load cell, proving ring, dial gauge, strain gauge, strain meter dan kabel-kabel penghubung. Dial gauge diletakkan pada jarak 1/3 dari panjang benda uji untuk mendapatkan data lendutan. Strain gauge diletakkan pada tengah bentang benda uji sehingga didapatkan besar regangan maksimum yang terjadi (gambar 5). Beban diberikan dari ujung bagian atas dan ujung bagian bawah ditahan. 


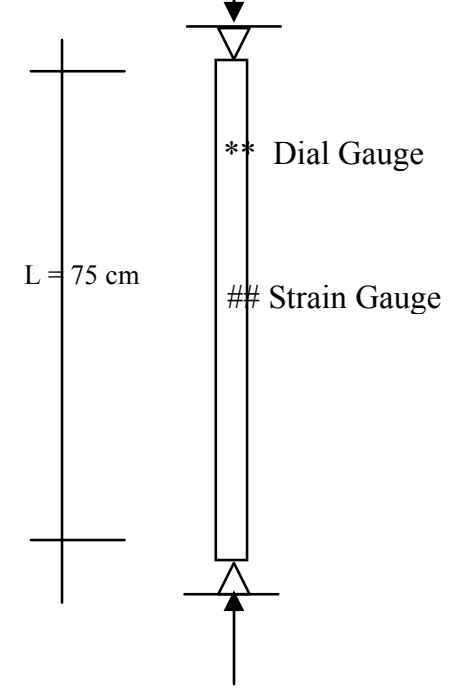

Gambar 5 Batang tekan.

Kabel dari strain gauge dihubungkan dengan strain meter. Selanjutnya pembebanan diberikan secara bertahap dengan penambahan beban secara konstan. Besarnya beban dibaca dengan proving ring dengan kapasitas 10000 lbf. Pembebanan yang dilakukan adalah pembebanan terpusat.

Pengujian lentur dengan panjang $65 \mathrm{~cm}$. Pengujian lentur dilakukan pada loading frame ukuran $(120 \times 80) \mathrm{cm}$. Benda uji diletakkan di atas tumpuan sendi rol dengan jarak tumpuan dari masing-masing ujung sebesar $12.5 \mathrm{~cm}$ (gambar 6). Dial gauge diletakkan pada tengah bentang benda uji pada loading frame serta pada jarak $10 \mathrm{~cm}$ dari tumpuan. Strain gauge diletakkan pada tengah bentang yang kabelnya dihubungkan dengan strain meter untuk mendapatkan data regangan. Pembebanan yang dilakukan adalah pembebanan terpusat pada tengah bentang secara bertahap dengan penambahan beban secara konstan yang besarnya beban dibaca pada proving ring yang berkapasitas 10000 lbf. Pembebanan dilakukan sampai kondisi baja mencapai leleh.

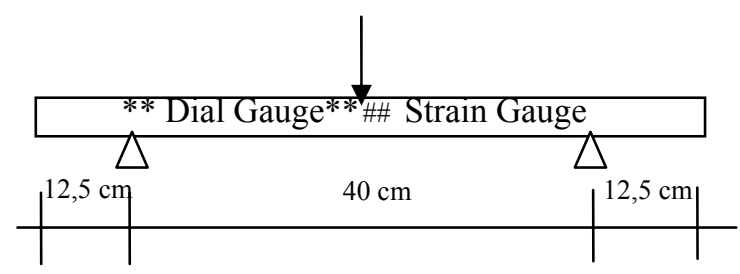

Gambar 6 Uji lentur. 
Pengumpulan data dilakukan pada saat pengujian berlangsung secara bertahap tergantung pada tahapan peningkatan pemberian beban. Pada saat pemberian beban dilakukan pencatatan besarnya regangan yang terjadi dibaca pada alat strain meter, besarnya beban yang diberikan dibaca dari alat proving ring serta besarnya lendutan yang terjadi dibaca dari alat dial gauge yang dilakukan secara bersama-sama oleh operator. Sebelumnya data geometrik dan berat sendiri dari masing-masing benda uji baja tabung kotak dicatat dan dikumpulkan.

\subsection{Analisis Data}

Langkah-langkah analisis data sebagai berikut:

1. Data regangan dihitung sehingga didapatkan nilai tegangan baja yang diperoleh dengan mengkorelasi dengan data dari hasil uji tarik.

2. Membandingkan hasil penelitian dengan teori yang sesuai.

3. Data tegangan leleh baja $\left(f_{y}\right)$, berat sendiri profil dan geometri penampang dianalisis secara statistik untuk mendapatkan nilai rata-rata $(\mu)$, nilai standar deviasi $(\sigma)$ dan koefisien variasi $(\Omega)$.

4. Dilakukan perhitungan nilai faktor reduksi $(\phi)$ mengikuti prosedur berikut ini:

a. Tentukan nilai indeks realibilitas $\beta$.

b. Asumsikan harga $\mathrm{r}^{*}$ awal untuk iterasi pertama,

c. Untuk variabel non-normal maka dihitung harga $\sigma_{x_{i}}^{N}$ dan $\mu_{x_{i}}^{N}$ dengan rumus:

$$
\begin{aligned}
\mu_{x_{i}}^{N} & =x_{i}^{*}-\sigma_{x_{i}}^{N} \Phi^{-1}\left[F_{x_{i}}\left(x_{i}^{*}\right)\right] \\
\sigma_{x_{i}}^{N} & =\frac{\phi\left\{\Phi^{-1}\left[F_{x_{i}}\left(x_{i}^{*}\right)\right]\right\}}{f_{x_{i}}\left(x_{i}^{*}\right)}
\end{aligned}
$$

d. Partial derivatives:

$$
\left(\frac{\partial g}{\partial x_{i}^{\prime}}\right)_{*}=\sigma_{x_{i}} \frac{\partial g}{\partial x_{i}}
$$

e. Hitung nilai arah cosinus menggunakan persamaan:

$$
\alpha_{i}^{*}=\frac{\left(\frac{\partial g}{\partial x_{i}^{\prime}}\right)_{*}}{\sqrt{\sum_{i}\left(\frac{\partial g}{\partial x_{i}^{\prime}}\right)_{*}^{2}}}
$$


f. Hitung harga titik keruntuhan disain:

$$
x_{i}^{*}=\mu_{x_{i}}-\alpha_{i}^{*} \cdot \beta \cdot \sigma_{x_{i}}
$$

g. Hitung nilai mean resistance $(\phi)$

$$
\phi_{i}=1-\alpha_{i}^{*} \cdot \beta \cdot x_{i}
$$

h. Hitung dalam nilai nominal dengan faktor bias (v)

$$
v_{R}=R_{n} / R
$$

\section{$5 \quad$ Hasil dan Pembahasan}

Hasil pengujian lentur terhadap baja tabung kotak diperoleh data hubungan beban-regangan, beban-lendutan dan tegangan-regangan. Grafik hubungan untuk hasil pengujian lentur dapat dilihat pada grafik 1, 2 dan 3. Besarnya tegangan leleh dan geometri penampang dapat dilihat pada tabel 1 dan tabel 2.

Tabel 1 Geometri dan berat sendiri baja tabung.

\begin{tabular}{|c|c|c|c|c|}
\hline No & $\begin{array}{c}\mathbf{b} \\
(\mathbf{c m})\end{array}$ & $\begin{array}{c}\mathbf{d} \\
(\mathbf{c m})\end{array}$ & $\begin{array}{c}\mathbf{t} \\
(\mathbf{c m})\end{array}$ & $\begin{array}{c}\text { Berat sendiri } \\
(\mathbf{k g} / \mathbf{m})\end{array}$ \\
\hline 1 & 2.01 & 4.01 & 0.2 & 1.051 \\
\hline 2 & 2.02 & 4.02 & 0.205 & 1.0521 \\
\hline 3 & 2.03 & 4.00 & 0.22 & 1.0552 \\
\hline 4 & 2.01 & 4.01 & 0.22 & 1.0511 \\
\hline 5 & 2.02 & 4.02 & 0.22 & 1.0514 \\
\hline 6 & 2.025 & 4.02 & 0.22 & 1.0521 \\
\hline 7 & 2.015 & 4.02 & 0.22 & 1.0520 \\
\hline
\end{tabular}

Tabel 2 Tegangan baja dan beban pada kondisi leleh.

\begin{tabular}{|c|c|c|}
\hline No & $\begin{array}{c}\text { Tegangan baja }\left(\mathbf{F}_{\mathbf{y}}\right) \\
\left(\mathbf{k g} / \mathbf{c m}^{\mathbf{2}}\right)\end{array}$ & $\begin{array}{c}\text { Beban terpusat }(\mathbf{P}) \\
(\mathbf{k g})\end{array}$ \\
\hline 1 & 3020.5160 & 902.950 \\
\hline 2 & 3038.2194 & 857.950 \\
\hline 3 & 3389.1009 & 992.950 \\
\hline 4 & 3395.7242 & 947.950 \\
\hline 5 & 3160.9335 & 992.950 \\
\hline 6 & 3411.8249 & 1037.950 \\
\hline 7 & 3425.0821 & 1127.950 \\
\hline
\end{tabular}

Dari hasil pengujian tekan baja tabung diperoleh data hubungan bebanregangan, beban-lendutan dan tegangan-regangan. Dari grafik tegangan- 
regangan ditentukan besarnya tegangan baja dan dapat dilihat pada tabel 4. Data geometri penampang dapat dilihat pada tabel 3 .

Tabel 3 Geometri dan berat sendiri baja tabung kotak.

\begin{tabular}{|c|c|c|c|}
\hline No. & $\begin{array}{c}\text { b } \\
(\mathbf{c m})\end{array}$ & $\begin{array}{c}\mathbf{d} \\
(\mathbf{c m})\end{array}$ & $\begin{array}{c}\mathbf{t} \\
(\mathbf{c m})\end{array}$ \\
\hline 1 & 2.01 & 4.005 & 0.21 \\
\hline 2 & 2.01 & 4.02 & 0.22 \\
\hline 3 & 2.015 & 4.01 & 0.22 \\
\hline 4 & 2.01 & 4.02 & 0.22 \\
\hline
\end{tabular}

Tabel 4 Tegangan baja pada kondisi Buckling.

\begin{tabular}{|c|c|c|}
\hline No. & $\begin{array}{c}\text { Tegangan baja }\left(\mathbf{F}_{\mathbf{y}}\right) \\
\left(\mathbf{k g} / \mathbf{c m}^{\mathbf{2}}\right)\end{array}$ & $\begin{array}{c}\text { Beban } \\
\mathbf{( k g )}\end{array}$ \\
\hline 1 & 2022.0345 & 3029.376 \\
\hline 2 & 2137.0835 & 2812.992 \\
\hline 3 & 2357.7968 & 2812.992 \\
\hline 4 & 2344.4729 & 3029.376 \\
\hline
\end{tabular}

Dari perhitungan diperoleh nilai faktor reduksi $(\phi)$ untuk lentur dan tekan:

Tabel 5 Faktor Reduksi $(\phi)$.

\begin{tabular}{|c|c|c|}
\hline$\beta$ & $\phi$ Lentur & $\phi$ Tekan \\
\hline 3 & 0.8823 & 0.5195 \\
\hline 2.5 & 0.9021 & 0.5475 \\
\hline 2 & 0.9225 & 0.5759 \\
\hline 1.5 & 0.9438 & 0.6047 \\
\hline
\end{tabular}

Dari perhitungan faktor reduksi $(\phi)$ lentur diperoleh untuk indeks keandalan $\beta=3$, faktor reduksi lentur $=0.8823$ dan faktor reduksi tekan $=0.5195$. Sedangkan LRDF-AISC menentukan dengan $\beta=3$ faktor reduksi lentur $=0.9$ dan faktor reduksi tekan $=0.85$. Faktor reduksi pada hasil pengujian ini berbeda dengan yang ditetapkan LRFD-AISC disebabkan variable-variabel yang diperhitungkan berbeda nilainya. Besar koefisien variasi tegangan leleh baja lentur untuk LRFD $\Omega_{\mathrm{F}}=0.05$, dari hasil pengujian diperoleh $\Omega_{\mathrm{F}}=0.0646$. Koefisien variasi modulus penampang LRFD, $\Omega_{\mathrm{s}}=0.03$ dari hasil pengujian diperoleh $\Omega_{\mathrm{s}}=0.0448$. Selain itu yang menyebabkan perbedaan itu ialah harga rasio rata-rata nominal dengan harga rata-rata. Dari perhitungan faktor reduksi lentur rasio tegangan dan modulus penampang masing-masing $\mathrm{v}_{\mathrm{F}}=0.9720$ dan $\mathrm{v}_{\mathrm{s}}=1.0158$. Untuk faktor reduksi tekan rasio tegangan dan rasio luas penampang, $\mathrm{v}_{\mathrm{F}}=1.4317$ dan $\mathrm{v}_{\mathrm{Ag}}=1.0073$. 
Dari tabel terlihat bahwa semakin kecil harga $\beta$, berarti semakin besar probability of failure $\left(\mathrm{p}_{\mathrm{f}}\right)$ maka harga faktor reduksi semakin besar. Fenomena ini menunjukkan bahwa secara statistik perlu kajian mendalam terhadap beberapa disain perhitungan dan asumsi faktor reduksi kekuatan di Indonesia.
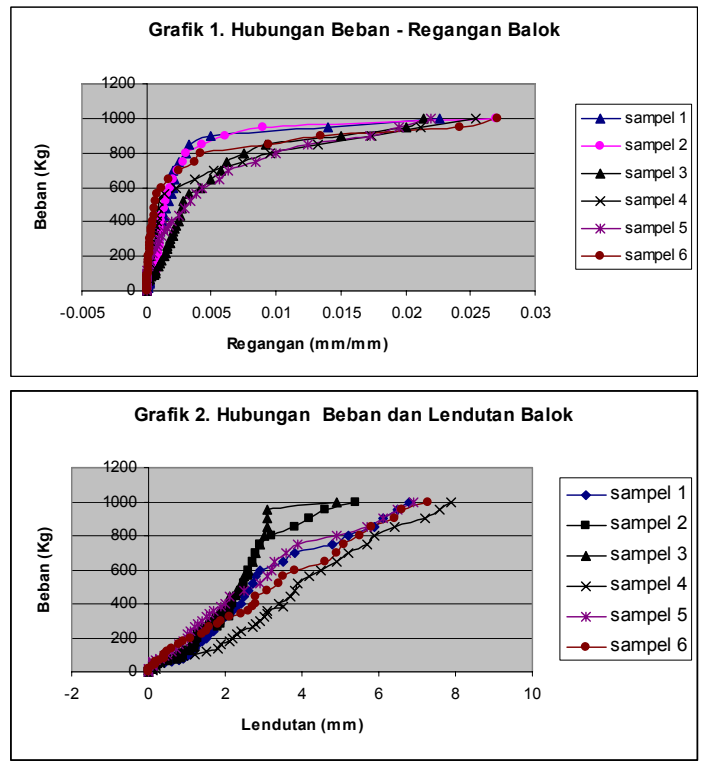

\section{$6 \quad$ Kesimpulan}

Dari hasil pembahasan yang telah dilakukan, dapat diambil kesimpulan sebagai berikut:

1. Nilai faktor reduksi $(\phi)$ untuk batang tekan dengan indeks keandalan $\beta=3$ dari hasil pengujian ini diperoleh $\phi_{\mathrm{c}}=0.5195$.

2. Nilai faktor reduksi $(\phi)$ untuk lentur dengan indeks keandalan $\beta=3$ dari hasil pengujian diperoleh $\phi_{\mathrm{b}}=0.8823$.

3. Perbedaan nilai faktor reduksi $(\phi)$ pada hasil pengujian dengan nilai faktor reduksi $(\phi)$ yang ditetapkan LRFD-AISC disebabkan beberapa hal antara lain:

a. Rasio harga rata-rata nominal dengan harga rata-rata.

b. Koefisien variasi $(\Omega)$ dari variabel.

c. Distribusi dari variabel yang digunakan dalam perhitungan. Pada pembahasan distribusi yang digunakan dalam perhitungan diasumsikan sesuai dengan rekomendasi yang diberikan.

4. Dari hasil perhitungan baik untuk batang tekan maupun lentur diketahui bahwa dengan semakin kecil indeks keandalan $(\beta)$, nilai faktor reduksi $(\phi)$ akan semakin besar. 


\section{Daftar Pustaka}

1. American Institute of Steel Construction, Inc. (AISC), Load and Resistance Factor Design Specification for Structural Steel Buildings, Chicago, IL (1999).

2. Ang, A. H-S. \& Tang, W. H., Konsep-Konsep Probabilitas dalam Perencanaan dan Perancangan Rekayasa Prinsip - Prinsip Dasar, Jilid 1. Penerbit Erlangga, Jakarta (1992).

3. Ang, A.H-S \& Tang, W.H., Probability Concepts in Engineering Planning and Design Volume II-Decision, Risk and Reability, John Wiley \& Sons (1984).

4. Ellingwood, B. R., Probability Based Load Criteria for Structural Design, 283-288.

5. Ellingwood, B.R. \& Tekie, P.B., Wind Load Statistic for Probability Based Structural Design, Journal of Structural Engineering, 453-463 (1999).

6. Hatmoko, Y. \& Lisantono, A., Analisis Keandalan Struktur, Penerbit Universitas Atmajaya, Yogyakarta (1998).

7. Kristijanto, H., Faktor Reduksi Tahanan pada Perencanaan Struktur Baja di Indonesia dengan Load and Resistance Factor Design, Jurnal Teknologi dan Rekayasa Torsi Mei, 19-23 (1996).

8. Potma, A. P. \& De Vries, J. E., Konstruksi Baja Teori Perhitungan dan pelaksanaan. PT. Pradnya Paramita, Jakarta (1991).

9. Ranganathan, R. Reliability Analysis and Design of Structures. Tata Mc Graw-Hill Publishing Company Limited New Dehli (1990).

10. Ravindra, M. K. \& Galambos, T. V., Load and Resistance Factor Design for Steel, Journal of the Structural Division 104 ST9, 1337 - 1353 (1987).

11. Roka, F. N., Studi tentang Faktor Beban \& Tahanan Akibat Beban Gempa di Indonesia pada Struktur Beton Bertulang, Master thesis, Institut Teknologi Sepuluh November, Surabaya (2001).

12. Salmon, C.G. \& Johnson, J. E. Struktur Baja Desain dan Perilaku dengan Penekanan pada Load \& Resistance Factor Design. PT Gramedia Pustaka Utama, Jakarta (1992).

13. Sidi, I. D., Penggunaan Metoda LRFD dalam Perencanaan Komponen Struktur Baja Di Indonesia, Lustrum VII HMS ITB, 1-12 (1990).

14. Suhendro, B., Teori Model Struktur dan Teknik Eksperimental. Kursus Singkat Metoda Penelitian Secara Numerik dan Eksperimental, Pusat antar Universitas Ilmu Teknik Universitas Gajah Mada (1991).

15. Yura, J. A., Galambos, T. V. \& Ravindra, M. K., The Bending Resistance of Steel Beams, Journal of the Structural Division 104 ST9, 1355-1370 (1978). 